Davies, P. Francis, P. and Greer, C. (2007) 'Victims, Crime and Society', in P. Davies, P. Francis, C. Greer (eds.) Victims, Crime and Society, London: Sage, pp9.

\title{
VICTIMS, CRIME AND SOCIETY
}

\section{Chapter 1}

\section{Introduction}

Social Divisions as Social Categories

Inequality, Risk and Victimisation

Media Representation and Victims of Crime

Researching Victims and Victimisation

Political and Policy Responses to Victims of Crime

Political Economy of Criminal Victimisation

Format and Structure of the Book

References

\section{Introduction}

The phrase 'the rich get richer and the poor get prison' is an old cliché but one that gets to the very heart of this book. Our central organising theme is the nature of criminal victimisation in relation to the intersecting and overlapping social divisions of class, race, age and gender. Beneath this rubric, the book explores the unequal distribution of criminal victimisation, the patterning and nature of risk, the experiences of crime victims as groups and individuals, and the social, political and criminal justice response to both crime victims and criminal victimisation. It foregrounds how the major social divisions in England and Wales - class, race, age and gender - provide a useful starting point for understanding the complex and dynamic nature of criminal victimisation in society. The book also explores the frequent tensions between social divisions, criminal victimisation, and state policy and practice. Specifically chapters within this book: 
- Introduce the importance of social division - class, race, age, gender - to understanding crime victims and criminal victimisation.

- Examine the importance of media representation for understanding social divisions, inequality and criminal victimisation.

- Map the unequal distribution of criminal victimisation in relation to social divisions and inequalities, and examine how victimisation impacts upon and is experienced differentially by a range of groups and individuals.

- Evaluate the various political and policy responses to crime victims and criminal victimisation and assesses the role of the voluntary and community sectors in supporting victims of crime.

- Explore the political, cultural and social context of criminal victimisation and reviews key theoretical, methodological and empirical approaches which are important for understanding criminal victimisation in contemporary society.

Our aim in the rest of this Introductory chapter is to map out the core themes of the book, identify various 'golden threads' that run throughout its pages and, in so doing, introduce, contextualise and interconnect the various chapters that follow. Firstly, we introduce the concept of social divisions as social categories and identify their constructed nature. Second, we examine the connectedness between social divisions, inequality and victimisation. Third, we introduce the importance of media analysis to an understanding of victims, crime and society. Fourth, we outline the various social research methods that have been used to help understand the nature, extent and impact of criminal victimisation. Fifth, we discuss political and policy responses to victimisation. Sixth, we situate victimisation within a broader theoretical framework. And finally, this chapter by introduces the various pedagogic features that we have used within the book, and present an outline of each chapter's structure.

\section{Social Divisions as Social Categories}

Everyday social existence involves the definition and continual reassessment of "who we are'. An important part of defining 'who we are' is determining who we are not. Our sense of 'self', therefore, our construction of 'who we are', is defined to a 
significant extent in contradistinction to conceptions of the 'other'. Notions of 'self' and 'other' can be isolated and highly individualised or shared and deeply embedded in culture. Sometimes they are institutionalised and become custom or law. Sometimes they remain marginal, and are considered quirky or eccentric. Sometimes their expression provokes censure and approbation. What is crucial is that constructions of 'self' and 'other' are intimately connected to the power relations that permeate the social and cultural world. We all live in a set of patterned and structured relations of unequal status and power - political, cultural or economic, for example. These relations can both free up and constrain our everyday lives. Having more money opens up certain opportunities which remain closed to those who have less. Having power and influence may open doors which would otherwise remain shut. These relations of power which help to shape our everyday experiences are bounded by social divisions.

Social divisions are social categories. Such categories can include race, gender, age, class, sexuality, disability, mental health and physical disability. Social categories are not static, but rather dynamic and change over time, space and place. As Best (2005: 324) states, "Social categories are not simply given, they have to be established and maintained and the process through which they appear is known as social division". They are situated historically, culturally, economically, and politically. Cultural and economic transformations over the last two decades, such as deindustrialisation and globalisation, have each impacted upon the nature of social division. Best (2005: 2), for example, discusses how in recent years the concept of globalisation has "racialised our notions of citizenship, and led us to question the validity of the nation state as a political entity" (Best 2005: 2). In one sense, social divisions are arbitrary. Yet they are also enduring. For Best (2005) the most enduring social divisions are those we believe are rooted in nature. In this sense, the most enduring social divisions portray continuity. Being young and working class, for example, continues to represent disadvantage, marginalisation and exclusion.

We are conscious of the problems relating to structuring the book according to what may appear, superficially at least, to be distinct and separate structural variables. From the outset we want to acknowledge that we recognise that the intersectionalties of class-race-age-gender or multiple inequalities (Daly 1993) variously combine "as 
intersecting, interlocking and contingent" (Daly 1997: 33). Indeed, we could have stretched the content of the book to include chapters on sexuality, mental health and disability, and we discussed this as editors and authors. And we may have done so were it not for the fact that, in relation to crime victims and criminal victimisation, these three areas remain under-researched.

The four social categories upon which this book primarily focuses - class, race, age, and gender - happen also to be the major social inequalities in our society. To be poor, to be black, to be young and to be female, simultaneously represents different distinct social categories with combined significance and relation to relative disadvantage, exclusion, marginalisation and powerlessness. We do not all start life equally. We come into it as unequal individuals. Advantage and disadvantage, therefore, are with us from the start, and the nature and impact of inequalities persist and change over time, place and space. Moreover, inequality is situated across and within generations. Our experiences in childhood may well affect our experiences later in life; and these will often affect our children's experiences as well. Who we fall in love with is often constrained by inequalities. And, importantly for this book, our experiences, fears and perceptions of crime and victimisation are experienced through social divisions of inequality.

In the chapters that follow, Hazel Croall explores class (Chapters 3 and 4), Sandra Walklate and Pamela Davies explore gender (Chapters 6 and 7), Peter Francis explores race and age (Chapters 5 and 8), Azrini Wahidin and Jason Powell explore age (Chapter 9), and Chris Greer and Pamela Davies explore the connections between social divisions in the context of media representation (Chapter 2) and criminal injustice (Chapter 10) respectively.

To read more about social divisions as social categories read:

Best, S. (2005) Understanding Social Divisions London: Sage

Carrabine, E. Iganski, P. Lee, M. Plummer, K. South, N. (2004) Criminology A Sociological Introduction London: Routledge

Croall, H. (1998) Crime and Society in Britain London: Longman 


\section{Inequality, Risk and Victimisation}

Whereas social division is the central organising theme of the book as a whole, individual chapters are connected together by four 'golden threads'. These are: social inequality, risk and victimisation; media representation and victims of crime; researching crime and victimisation; and political and policy responses to victims of crime.

Since the mid 1990s, England and Wales has experienced a downturn in reported and recorded rates of crime and victimisation. For example, the British Crime Survey (BCS) for 2005/06 reports that crime and victimisation is stabilising after long periods of reduction. In 2005/06 there were 10.9 million crimes committed against adults living in households in England and Wales (Walker et al 2006). There were 5.6 million crimes recorded by the police for 2005/06. Since peaking in 1995, the BCS estimates that crime has reduced by $44 \%$, representing 8.4 million fewer crimes, with burglary (59\%) and vehicle crime (60\%) falling by more than half, and violent crime by $43 \%$. Indeed, the BCS suggests that "The risk of becoming a victim of crime has fallen from $40 \%$ at its peak in 1995 to $23 \%$ according to BCS interviews in 2005/06, representing just over 6 million fewer victims. This is the lowest level recorded since the BCS began in 1981" (Walker et al 2006: 13). Police data indicate that recorded rates for burglary and theft of and from vehicles have continued to fall over the same period. Furthermore, although police figures reveal an increase in recorded crime over the same period up until 2004 (largely as a result of the $\mathrm{NCRS}^{1}$ ), the figures for 2005/06 indicate a reduction from the previous year. In general terms, and without disaggregating the crime and victimisation figures, England and Wales is probably a safer place in 2005/06 than it was in the mid 1990s.

However it must be noted that such figures:

\footnotetext{
${ }^{1}$ The National Crime Recording Standard (NCRS) was introduced in April 2002 to ensure better consistency of crime recording across force areas and offence categories. Visit http://homeoffice.gsi.gov.uk/rdscountrules.html for a more detailed discussion of the nature and detail of the NCRS.
} 
- Do not take account of rates of reporting and recording by victims of crime both to BCS interviewers and police officers. Any increase or decrease may reflect the sensitivity in which racist incidents are subsequently recorded and classified by the police and/or may be the result of a victim's predisposition to report their victimisation. Walker et al (2006), for example, confirm findings from previous surveys that suggest there are fairly high rates of under-reporting and underrecording of crime and victimisation, and that rates of both are contingent on a range of interrelated factors such as offence type, victim characteristics (young, old, black, white, male, female, straight, gay), previous experiences and, among other factors, perception of the police response.

- Mask variation in people's risk and vulnerability to crime and victimisation. The BCS has since its inception provided evidence that crime and victimisation are unevenly distributed across and between groups of individuals based upon their ethnicity, gender, age, class, lifestyle, relationships and so on. The BCS 2005/06 indicates that geographic patterns and concentrations of offences varied by crime type. Variations differed across regions; in urban and rural areas; by Crime and Disorder Reduction Partnership $\left(\mathrm{CDRP}^{2}\right)$ area; and between most employmentdeprived and least unemployment-deprived areas.

- Are unable to uncover the impact that crime and victimisation have on individuals. After all, the impact that victimisation has upon an individual is again dependent upon a range of factors, many of which are, to use Daly's phrase, intersecting, interlocking and contingent.

In examining the relationship between inequality, risk and victimisation, Mike Dixon and colleagues (2006) offer a useful introduction and overview of recent crime and social inequality data. Examining data drawn from the BCS alongside socio-economic data, they attempt to un-mask the unequal impact of crime.

\footnotetext{
2 The Crime and Disorder Act 1998 as amended by the Police Reform Act 2002 introduced a statutory responsibility on the police and local authorities to work together and with other relevant agencies and organistanisation within their area to prevent and reduce crime and disorder. As a result, there are at the time of writing 354 CDRPs in England and 22 CDRPs in Wales.
} 
First, they point out that both crime and public perceptions of it differ by income and area. Those with incomes less that $£ 10,000$ and those residing in deprived neighbourhoods are more likely to experience acquisitive crime, and more likely to pronounce themselves very worried about being physically attacked (see Table 1). Dixon et al (2006: 13) highlight three specific findings in relation to income, victimisation and concern. These are:

- Richer households are more likely to be victims of some crimes, such as vehicle crime and criminal damage.

- Poorer households are more likely to be victims of serious intrusive crime such as burglary, mugging and domestic violence.

- Poorer households are much more likely to report being very worried about specific types of crime and feeling unsafe when walking alone after dark. Importantly the difference in concern is greater that the difference in victimisation.

\section{ADD TABLE 1 HERE}

Obviously, there are broader issues at play here and they relate to an individuals ability to undertake avoidance behaviour and protect themselves and their household from crime and victimisation, their willingness to report their victimisation to an interviewer or the police, and their ability to deal with the cumulative physical and psychological effects of experiencing and worrying about victimisation. Nevertheless, the broad finding remains the same - that those people most likely to be victimised by crime and to experience social harm in England and Wales are often the most marginalised social groups living in the poorest areas (Zedner 2002). Vulnerability to crime, risk and fear of crime are exacerbated by social, economic and political exclusion.

Dixon et al provide similar findings for ethnicity, age and gender. However, the differential risk rates associated with specific categories of social division are considered in detail across the different chapters in this book. What we want to stress here is that these categories should not be viewed as static and separate but as interconnecting and closely related. Thus, recent BCS reports suggest that black and 
minority ethnic groups are more likely to be victims of crime, but this is because, on average they are more likely to be younger (Dixon et al 2006: 14). Once age is accounted for, risk and rates of vulnerability are minimal (Salisbury and Upson 2004). There are also interesting points to be noted in relation to age and gender. Young people, for example, are often the most likely to be criminally victimised, and risk of victimisation declines with age. But gender also affects the risk and vulnerability of younger and older people. Dixon et al (2006: 16) point out that while women are less likely to be to be victims until they reach the age of 65 , "they are more likely to be victims of domestic violence at any age".

Each chapter in this book focuses upon social inequality, risk and victimisation and their connections and interconnections with social categories of class, race, age and gender.

To read more about inequality, risk and victimisation read:

Cook, D. (1997) Poverty, Crime and Punishment London: Child Poverty Action Group

Dixon, M. Reed, H. Rogers, B. and Stone, L. (2006) Crime Share: The Unequal Impact of Crime London: Institute for Public Policy Research

Walker, A. Kershaw, C. Nichols, S. (2006) Crime in England and Wales 2005/06 Home Office Statistical Bulletin London: Home Office

\section{Media Representation and Victims of Crime}

The front cover of this book presents an image of legs and feet of people walking along a pavement. We don't know who they are, what they look like, whether they are male or female, black, mixed race, Asian, young or old. The cover is reflective of the second golden thread that runs the length of the book. The role of news media in constructing and (mis)representing crime victims and criminal victimisation. While the media do not necessarily tell us what to think, they can tell us what to think about. They are of fundamental importance to those who would promote a particular view of crime victims and criminal victimisation, or seek to challenge or change existing views. They are a key site on which policy makers seek to secure popular acceptance 
and legitimacy of new measures affecting victims of crime, and groups espousing competing values, interests and beliefs struggle to secure 'ownership' - and, with it, political power - of various victim-related issues and debates.

In the information age (Webster, 2005), where communications technologies occupy a central and increasingly important role in most people's lives, understanding complex social issues like crime and victimisation, control and social order requires engaging with media. As one of us has argued elsewhere (Greer, 2005: 157):

The rapid and relentless development of information technologies over the past 100 years has shaped the modern era, transforming the relations between space, time and identity. Where once 'news' used to travel by ship, it now hurtles across the globe at light speed and is available 24 hours-a-day at the push of a button. Where once cultures used to be more or less distinguishable in national or geographical terms, they now mix, intermingle and converge in a constant global exchange of information. Where once a sense of community and belonging was derived primarily from established identities and local traditions, it may now also be found, and lost, in a virtual world of shared values, meanings and interpretations. In short, media are not only inseparable from contemporary social life; they are, for many, its defining characteristic.

The 'problem of crime', as many have pointed out, is a socially constructed problem. What we mean by this is that, since most people have little first hand experience of crime and criminal victimisation, we are reliant on other sources of information for much of our knowledge about it. Few of these are more important than the media. Media representations influence what the issues of crime and criminal victimisation 'mean' to people. They help to socially construct these issues by presenting particular 'views of reality'. There is no necessary connection, however, between what is presented in media and what is happening 'in the real world'. The issues of crime and criminal victimisation, then, are highly mediatised issues. On this basis, it is our contention that any comprehensive sociological exploration of crime victims and criminal victimisation must engage with media and media representation. For a failure to engage with media in analyses of this nature is a failure to acknowledge one of the 
key sources through which the concepts of crime, victim and criminal victimisation are 'made to mean' in contemporary society.

One need only skim the chapter headings and index pages of the vast majority of victimology books to realise that media representations scarcely feature. This, for us, represents an important gap in the literature, and in this book we seek to contribute to filling that gap. It is not our intention to suggest that criminal victimisation had no external reality, or that this reality is 'unknowable' in any meaningful, empirical way. Nor indeed would we suggest that the reality of crime, inasmuch as it can be known empirically or experientially, is of secondary significance to what people believe to be the reality of crime. On the contrary, aligned with a critical criminological approach, and as noted already, we are keen to point out that criminal victimisation tends to be disproportionately concentrated among some of the most vulnerable, marginalised and powerless sections of society. For these groups the pains of victimisation are experienced not only most often, but also most acutely. What we would insist, however, is that popular understanding of this unequal distribution of pain and suffering, of the nature and extent of criminal victimisation, of the experiences of victimisation and fears of being a crime victim, of the measures that might be taken to reduce victimisation, of victims' needs and victims' rights - all these issues are, to a greater or lesser extent, shaped in the media.

In addition to Chapter 2 by Chris Geer which is dedicated to exploring media representations through an in depth analysis of general issues and specific cases studies, each successive chapter acknowledges in some sense the key role that media can play in defining, problematising and reshaping dominant conceptions and popular understandings of crime victims and criminal victimisation .

To read more about media representation and victims of crime read:

Chermak, S. (1995) Victims in the News: Crime and the American News Media, Boulder, CO: Westview Press.

Greer, C. (2003) Sex Crime and the Media: Sex Offending and the Press in a Divided Society, Cullumpton: Willan.

Jewkes, Y. (2004) Crime and the Media London: Sage. 


\section{Researching Crime and Victimisation}

The third golden thread that connect the chapters together concerns the methodologies and the tools and techniques used to find out about crime victimisation and victims of crime. Since the 1970s, the direct questioning of the victim of crime has been central to the victimological enterprise, some of the features of which are generic to social surveys whereas others are specific responses to the problems of studying victimisation (Davies et al 2003).

The belief that official recorded criminal statistics indicate more about the organisational processes involved in collation and collection than about levels of crime and criminal activity has had an enormous impact upon engaging criminologists in alternative and competing strategies of collecting data about crime, such as the utilisation of data other than that from the police (Maguire 2002). A further impetus to the development of victim surveys came from direct concerns for the victim within criminology and also within criminal justice policy. It was only with the growth in interest in victims of crime and criminal activity during the late 1970s in the United States of America and the 1980s in Britain, coupled with the enormous impact of feminist research and methodologies that information about victims of crime and victimisation slowly started to appear in the form of the crime survey (Goodey 2005). Since then, surveying victims has for many criminologists become one of the most flexible and rewarding research methodologies, facilitating the generation of details about the circumstances of the offence, relationships between victims and victim's experiences of the various criminal justice agencies. During the early 2000s the Home Office moved from only presenting the BCS and police recorded crime in separate reports to combining key findings of each and presenting these as an additional composite report (see for example Walker et al 2006).

Davies et al (2003) demonstrate how victimisation surveys have played an important role in criminology and in policy making by providing better estimates of the extent of crime and criminal victimisations than those provided by police data, and also by giving insights into victims' experiences, perceptions and worries of crime and of the criminal justice system. In a variety of ways, surveys of victims have been concerned 
with differing dimensions of victimisation. These include crime measurement and reasons for under-reporting and under-recording; the correlates of victimisation; the risk of victimisation; the fear of crime and its relationship to the probability of victimisation; the experience of crime from the viewpoint of victims; and the treatment of victims in the criminal justice system. In particular, five broad patterns in victim surveys are discernible. These are local cross-sectional sample surveys, 'appreciative surveys, national trend sample surveys, cross-national surveys and police 'consumer' surveys (Davies et al 2003; Spalek 2006).

Victimisation surveys, however, are not without criticism. These criticisms range from the simple, such as they can often assume a level of literacy and or understanding amongst the sample population that may not be available, to the more complex. In particular they have been criticised for not being able to get behind the mere appearance of things. The things that go on behind our backs, constitute the things we are not aware of (but which may still result in our victimisation) and these are much more difficult to capture by survey method; for example, not being able to provide estimates of 'victimless' crimes, not addressing crimes such as mass pollution, affecting large populations, and not providing measures of crimes, such as fraud..

Moreover, victimisation surveys are unable to situate and contextualise victimisation with the everyday lives and routine activities that each of us engages in. They are unable to situate our experiences of crime and victimisation within socio-economic, cultural and political contexts. In addition, surveys can often reflect the agenda and priorities of those carrying out the research or consultation rather than the participants involved as subjects. Victim surveys are closely tied to the confines of the criminological and victimological enterprises. Therefore, such surveys are often viewed as inappropriate to questions raised by forms of thinking which view such enterprises as constraining and instead seek to add a critical edge by locating victimisation in wider structural issues.

As a consequence, some victimologists have looked beyond the victimisation survey to more qualititative and ethnographic methods of research and inquiry. Indeed, many have heeded the clarion call for triangulation to pick and mix and match different 
methods for different areas of research. Sandra Walklate (2003: 41) for example has suggested that exploration of the complexity of human interaction through time and space demands a research agenda which goes beyond the victimisation survey. The kind of framework supported by Walklate is one that locates victimisation within a socio-economic, cultural and political context and which examines the processes that go on behind people's backs which contribute to the victims (and the crimes) we see as opposed to those we do not see. For Walklate research may involve comparison, triangulation of method and longitudinal studies.

Class, race, age and gender all play their part in locating victimisation in wider structural issues as do personal histories, habits and behaviours. Throughout the book, each chapter explores the ways in which victims of crime are rendered visible through documenting and cataloguing their experiences. They examine how criminal victimisation is measured and how unreported victimisation remains an issue, and trace the development of the ways in which the socially divided nature of victimisation is increasingly appreciated and understood.

To read more about researching victims and victimisation read:

Davies, P. Francis, P. and Jupp, V. (2003) Victimisation Theory, Research and Policy Basingstoke: Palgrave

Goodey, J (2005) Victims and Victimology Research, Policy and Practice London: Longman

Spalek, B. (2006) Crime Victims Theory Policy and Practice London: Palgrave

\section{Political and Policy Responses to Victims of Crime}

The final golden thread that connects each of the chapters together concerns the political and policy response to victims of crime.

Victims of crime that often appear in the public arena usually do so because they have made contact with the police (or the criminal justice system as witness). These individuals are already a selective category of crime victims and a socially divided group. They have become separated from other victims of crime and social harm 
because they have become part of the political and policy process, and thus, in relative terms, what we might call 'visible victims'. These are the people whose victimisation has come to official notice. Where public policy and practice for victims is concerned these might be considered the lucky ones. Their experiences are officially known about and they may qualify for assistance and support. Indeed they themselves might consider themselves the lucky ones.

However, even at this stage this may not be the case. For example they may experience secondary victimisation. Secondary victimisation occurs at the hands of criminal justice system staff or anyone else responding to an offence. It results from the insensitive treatment of victims of crime - often inadvertently - by the criminal justice system or by friends and acquaintances. For example, a child may have their experience questioned by a police officer or social worker casting doubt upon their truthfulness and integrity (Davies and Francis 2007).

Very few victims of crime seek help and public support and assistance of their own accord. For the vast majority of victims who become users of services provided by the criminal justice system or supportive provisions funded by the government, few will seek help spontaneously. Most will take up the offer of practical assistance and emotional support after having been referred by the police. For enormous numbers of people who are socially harmed or criminally victimised it is more difficult for them to access services and some are even excluded from making use of some schemes because they have not come into the public arena of the criminal justice system or managed to make their victimisation visible.

A range of supportive provisions and victim assistance schemes can be identified in most social systems across the world all of which will have differing relationships to their respective criminal justice systems. Some victimagogic services are at arms length or fully independent of the government and the criminal justice system, some are provided under statute, others by voluntary groups and charities. In England and Wales particularly since the 1990s, there has been a proliferation of different victimagogic activities blurring the boundaries of whether help and assistance is public, private or voluntary and whether it is offered as of right. For a discussion of the development of victim support and services consult Williams (1999) and Davies et 
al (2003). Landmark dates in the development of victim support and services are detailed in Table 2.

Table 2: Some Landmark Dates in the Development of Victim Support Policy

\begin{tabular}{|c|c|}
\hline 1964 & $\begin{array}{l}\text { Establishment of statutory criminal injuries compensation } \\
\text { arrangements }\end{array}$ \\
\hline 1972 & First UK women's refuge set up \\
\hline 1975 & Victim Support set up \\
\hline 1976 & First UK rape crisis centre set up \\
\hline 1981 & Creation of British Crime Survey \\
\hline 1982 & $\begin{array}{l}\text { Roger Graef's TV documentary on the treatment of women reporting } \\
\text { rape }\end{array}$ \\
\hline 1985 & $\begin{array}{l}\text { UN declaration of the basic principles of justice for victims of crime } \\
\text { and abuse of power }\end{array}$ \\
\hline 1986 & Child line set up \\
\hline 1987 & First national government funding for Victim Support \\
\hline 1990 & Victim's Charter \\
\hline 1991 & Criminal Justice Act \\
\hline 1996 & Victims Charter revised \\
\hline 1998 & Crime and Disorder Act - reparation for victims of young offenders \\
\hline 1999 & $\begin{array}{l}\text { Youth Justice and Criminal Evidence Act - vulnerable witness } \\
\text { provision }\end{array}$ \\
\hline 2004 & Domestic Violence, Crime and Victims Act \\
\hline 2004 & Victims Fund - to develop services for victims of sexual offending \\
\hline 2004 & $\begin{array}{l}\text { Establishment of the Victims Advisory Panel - giving victims a greater } \\
\text { voice in policy making }\end{array}$ \\
\hline 2005 & $\begin{array}{l}\text { Rebuilding Lives: Supporting Victims Green Paper - victim support to } \\
\text { prioritise practical and emotional help, as well as financial } \\
\text { compensation }\end{array}$ \\
\hline 2006 & $\begin{array}{l}\text { Code of Practice for Victims of Crime - creation of statutory } \\
\text { obligations on the Criminal Justice System to provide minimum } \\
\text { standard of service to victims }\end{array}$ \\
\hline
\end{tabular}




\section{Recruitment of a Commissioner for Victims and Witnesses}

Source Dixon et al (2006: 7)

Various contributions to this volume consider the nature and impact of the political and the policy response to victims of crime mostly in the context of England and Wales but comparisons with other jurisdictions are also used. There is one main unifying thread to this particular focal point and connected to this there are several key victimological debates that impact upon the major social divides under scrutiny. The singular unifying thread that contributions to this volume in respect of the nature and impact of the relationship between victims, public policy and practice can be summed up by the following questions:

- How appropriate are the various state responses to victimisation and victims and witnesses?

- What has been the political and policy response to specific victims of crime?

- How do victims of different types of criminal victimisation experience criminal justice systems and processes?

In this volume there are sections within chapters that specifically address questions about anti-social experiences, unfairness and bias, injustice and inequality, discrimination and prejudice as pertaining to criminal justice systems generally or to different components of systems i.e. the police, the courts, the CPS, the magistracy and judiciary, the prison and probation services.

However, in addition to the unifying thread identified in the questions above, there are several key victimological concerns and debates that repeatedly occur in reviewing the relationship between victims within the major social divisions under scrutiny in this volume and public policy and practice. Some of these discussions focus upon the absence of appropriate public policy and practices directed towards those who have been criminally victimised or socially harmed and which might aid their recovery. Other discussions focus upon the victim's representation or lack of representation and even neglect in criminal justice policy and practice. Another angle to these reviews and critiques focuses upon how public and criminal justice policy and practice can 
actually result in social harm and criminal victimisation. These sections of the volume effectively examine the ways in which people experience victimization as a result of criminal justice policy and practice and as a result of wider measures aimed at reducing crime and / or improving quality of life and well being. Additionally, several of the chapters highlight recent developments in the provision of mediation and restorative justice programmes as such philosophies appear to be penetrating the broader spectrum of criminal justice policy and practice generally.

From the above discussion it can be surmised that there have been numerous developments involving the victim of crime in state and charitable / voluntary sector policy and practice over the past four decades. Indeed, criminal justice policies in respect of victims have gathered increasing momentum. Many have had a positive impact, especially in terms of changing the status of the victim in the criminal justice system. Some measures have significantly improved victim's experiences in connection with helping achieve criminal justice whilst other developments over the last forty years or so have been helpful in meeting victims needs in the short, medium and longer term. Certain time periods can be identified with specific social groups achieving victimological recognition. The re-emergence of the feminist movement in the 1970s was enormously influential in the development of services for victims of rape, sexual assault and domestic violence well into the following decade in both the US and UK. In England and Wales developments in the 1990s were especially significant. This decade produced the Stephen Lawrence Inquiry, acknowledged police institutional racism and inadequacies surrounding public policies associated with black people crime, victimisation and criminal justice. The same decade also witnessed the rediscovery of popular punitiveness towards young offenders which youth victimology has since been heavily critical of.

Whist there have been positive gains for some crime victims there have also been some stalemate predicaments and even losses. In terms of stalemates, despite an array of victim-oriented activities and measures there continues to be a lack of any coherent victims policy and victims of crime continue to occupy a position defined by their need rather than by a notion of rights. Another stalemate situation is that victims' 'lived experiences' of criminal justice and its agencies - namely the police, courts and prosecution process - continue to be less positive than hoped. For example, much 
literature details the fragile nature of police - victim relations, especially when the victim represents a marginalised and oppressed group or individual - such as ethnic minorities, women, young people and those from low socio-economic positions. And finally in terms of losses, some victims continue to be further traumatised and victimised by inappropriate treatment from public sector services including the criminal justice system and other official bodies and authorities. Victimologically, excluded citizens and consumers of services are those that fall short of the socially acceptable stereotype of the 'ideal victim', people divided by policies dominated by such assumptions continue to be the forgotten or lost victim.

To read more about political and policy responses to victims of crime read:

Davies, P. and Francis, P. (2007) Victims in the Criminal Justice System London: Polity Press

Dignan, J. (2005) Understanding Victims and Restorative Justice Basingstoke: Open University Press

Spalek, B. (2006) Crime Victims Theory Policy and Practice London: Palgrave

\section{Political Economy of Criminal Victimisation}

In the previous sub sections we have introduced the central organising theme and the various golden threads that run throughout the various chapters. This penultimate section situates and locates the book within a broader theoretical and methodological framework - one that we hope is broadly critical in aim and approach. It is informed by the importance of delivering social justice.

As noted at various stages already, the contributors to this volume are concerned not only to explore and explain the nature and extent of criminal victimisation in contemporary society, but to understand the unequal distribution and experience of that victimisation through reference to social division and inequality. Inequality is understood as being a necessary by-product of the current political-economic and social-cultural arrangements of late modern society. Crime, victimisation, social division and inequality all simultaneously derive from and feed into wider structures of inclusion and exclusion, power and subordination, containment and control. As 
such, they are defining features of the contemporary social and criminal justice landscape.

A central contention of this book is that criminal victimisation is felt most often and most acutely by the most marginalised and powerless sections of society. At the same time, prevailing definitions of crime victim and criminal victimisation - in terms of who can or cannot legitimately claim victim status, who is or is not deserving of social support or media attention - does much to reify dominant white, male, middleclass, heterosexual discourses on crime and control. They reinforce rather than challenge existing structures of power. In so doing, they help to maintain the social, political and economic conditions under which much criminal victimisation takes place. It is within this critical criminological framework, sensitised in particular to the issues of inequality, social justice, and inclusion and exclusion, that all the contributions in this book are located. For these reasons, this book is a political book.

Critical criminology has a long and varied history within the academy. Partly in response to the a-theoretical, a-historical, situationally-oriented approaches of the administrative criminologies resulting from the Home Office 'what works' mantra of the 1980s, critical criminology has undergone something of a recent resurgence. One of its central aims is to reinforce and tighten the links between criminology and its theoretical and political moorings, at a time when administrative criminology risks casting it adrift from both. Whilst administrative criminologists pay at best secondary attention to the causes of crime, critical criminologists consider an appreciation of aetiology to be fundamental, not least because many of the sources of criminal behaviour, and thus criminal victimisation, can be found in the political and economic structures of late capitalist societies. Whilst administrative criminologists retain a narrow definition of crime - in many ways reflecting tabloid representations of street violence, burglary, car theft and vandalism - critical criminologists are keen to convey that much suffering through criminal victimisation results from the activities of the powerful. Corporate and white collar offending, state crimes, deaths in custody, everyday experiences of racial and sexual violence and prejudice, and social exclusion can all be understood in terms of political and economic power and the unequal distribution of social justice in society. 
Thus, a critical criminological approach is shared across each of the contributions in this volume. Whether discussing race, age, gender, class or media constructions of these social categories and their connection to images of crime and victimisation, analysis is informed by an appreciation of the political economy of crime and criminal victimisation, and a desire to highlight victimisation caused by the powerful as a pressing and ongoing concern.

To read more about the political economy of criminal victimisation read:

Cook, D. (2005) Criminal and Social Justice London: Sage

Hillyard, P. Pantazis, C. Tombs, S. Gordon, D. (eds.) (2004) Beyond Criminology Taking Harm Seriously London: Pluto Press

Mawby, R. and Walklate, S. (1994) Critical Victimology London: Sage

\section{Format and Structure of the Book}

To ensure consistency across all chapters in terms of the presentation of theory, research, policy and practice, and to secure a thorough review of all aspects of the academic and scholarly research literature, as editors and co-authors we were keen to identify from the outset a common format or component listing for each chapter that we hoped individual chapter authors would cover. Thankfully each of the authors agreed and as a result, each author ensured that their chapters included the following:

- A critical review of the theoretical and research literature on the area of study.

- An assessment of the development of any policy and legislative responses.

- A discussion on key developments / issues in the area of study.

- A discussion on any future research directions.

- A concise summary and conclusion.

In addition, each of the chapters provides:

- A glossary of key terms used within the body of the chapter.

- Questions for reflection and discussion. 
- An annotated bibliography.

In outlining this format for each chapter, we were particularly keen to balance the authors wish to explore and discuss what they wanted to in relation to the particular substantive area that they were writing on and the needs of the reader new to the discipline of victimology and the study of victimisation and victims of crime. In doing so, we think that the format strengthens the student centred nature of the book and allows for cross-referencing to be made within and between chapters.

The structure of the book is as follows:

\author{
Chapter 2 - Chris Greer News Media, Victims and Crime \\ Chapter 3 - Hazel Croall Social Class, Social Exclusion, Victims and Crime \\ Chapter 4 - Hazel Croall White Collar and Corporate Victims of Crime \\ Chapter 5 - Peter Francis Race, Ethnicity, Victims and Crime \\ Chapter 6 - Sandra Walklate Men, Victims and Crime \\ Chapter 7 - Pamela Davies Women, Victims and Crime \\ Chapter 8 - Peter Francis Young People, Victims and Crime \\ Chapter 9 - Azrini Wahidin and Jason Powell Old Age, Victims and Crime \\ Chapter 10 - Pamela Davies Criminal (In)Justice for Victims?
}

\title{
References
}

Best, S. (2005) Understanding Social Divisions London: Sage

Carrabine, E. Iganski, P. Lee, M. Plummer, K. South, N. (2004) Criminology A Sociological Introduction London: Routledge

Chermak, S. (1995) Victims in the News: Crime and the American News Media, Boulder, CO: Westview Press.

Cook, D. (2005) Criminal and Social Justice London: Sage

Cook, D. (1997) Poverty, Crime and Punishment London: Child Poverty Action Group

Daly, K. (1997) 'Different ways of conceptualising sex/gender in feminist theory and their implications for criminology' Theoretical Criminology 1(1): 25-51 
Daly, K. (1993) 'Class-race-gender: sloganeering in search of meaning' Social Justice 20(1-2): 56-71

Davies, P. and Francis, P. (eds.) (2007) Victims in the Criminal Justice System London: Polity Press

Davies, P. Francis, P. and Jupp, V. (eds.) (2003) Victimisation Theory, Research and Policy Basingstoke: Palgrave

Dignan, J. (2005) Understanding Victims and Restorative Justice Basingstoke: Open University Press

Dixon, M. Reed, H. Rogers, B. and Stone, L. (2006) Crime Share: The Unequal Impact of Crime London: Institute for Public Policy Research

Goodey, J (2005) Victims and Victimology Research, Policy and Practice London: Longman

Greer, C. (2003) Sex Crime and the Media: Sex Offending and the Press in a Divided Society, Cullumpton: Willan.

Hillyard, P. Pantazis, C. Tombs, S. Gordon, D. (eds.) (2004) Beyond Criminology Taking Harm Seriously London: Pluto Press

Jewkes, Y. (2004) Crime and the Media London: Sage

Maguire, M. (2002) 'Crime statistics: the data explosion and its implications' in Maguire, M. Morgan, R. and Reiner, R. (eds.) The Oxford Handbook of Criminology Third Edition Oxford: Clarendon Press

Salisbury H and Upson A (2004) Ethnicity, Victimisation and worry About Crime: Findings from the 2001/02 and 2002/03 British Crime Survey Findings 237 London: Home Office

Spalek, B. (2006) Crime Victims Theory Policy and Practice London: Palgrave

Walker, A. Kershaw, C. Nichols, S. (2006) Crime in England and Wales 2005/06 Home Office Statistical Bulletin London: Home Office

Walklate, S (2003) 'Can there be a feminist victimology?' in Davies, P. Francis, P. and Jupp, V. (eds.) Victimisation Theory, Research and Policy Basingstoke: Palgrave

Mawby, R. and Walklate, S. (1994) Critical Victimology London: Sage

Webster, F, (2005) 'Making Sense of the Information Age: Sociology and Cultural Studies', Information, Communications and Society, 8, 4: 439-458.

Williams, B. (1999) Working with Victims of Crime London: Jessica Kingsley 
Zedner, L. (2002) Victims in Maguire, M. Morgan, R, and Reiner, R. (eds.) The Oxford Handbook of Criminology Third Edition Oxford: Clarendon Press 